\begin{tabular}{ccc}
\hline International Journal of Engineering \& Technology, $7(1.4)(2018) 54-60$ \\
SPC \\
Website www.sciencepubco.com/index.php/IJET \\
Research paper
\end{tabular}

\title{
Industrial method of Pre-Cast Construction technologies and its break-even point study
}

\author{
Luke Judson* \\ Bhagwan Mahavir School of Architecture, Sonepat, Haryana, India \\ AuthorE-mail: ar.lucky8@gmail.com
}

\begin{abstract}
The applications of precast concrete systems have attained accelerated progress worldwide, due to several aspects, such as good quality control, speedy construction, economy, minimizing waste, pollution free, modern construction equipment and advanced concrete technologies. Due to lack of systematic understanding and awareness in the Architecture and Construction industry this method is not majorly used. In this paper describes available technologies and bringing out the advantages and benefits of these technologies by bringing out the 'breakeven point or equal cost component' in comparison with a traditional construction. Comparison based on specific building components, labor cost and benefits due to early completion.
\end{abstract}

Keywords: Industrial method of Pre-Cast Construction, Pre-Cast Construction of High-Rise buildings, Pre-Cast Construction.

\section{Introduction}

Pre-cast construction is based on the principle where standardized building modules or sections are casted, prepared and cured in a controlled factory environment then transported to site for erection. The erection is done with the help of cranes and lifting equipment. Even though precast construction was initiated in 1950 's in India, there are very few works done in the high rise building sector. Developing countries are using these technology very extensively. In recent years Government has initiated the use of this technology in construction of residences to urban poor. In Architecture and construction choosing a technology plays a very important role. The study of Break-even-point helps to choose these kind of technologies.

\section{Methodology}
1. Literature
2. Theoretical framework
3. Case study
4. Findings
5. Comparisons and Analysis
6. Conclusions
7. References

\section{Literature}

In this section discuss the various methods of industrialized precast concrete components production and what breakeven point is. Industrialized methods used for the production of structural precast concrete components for buildings are Circulation flow production and Production in long lines of beds ('Precast Concrete Structure' [1]).

\subsection{Circulation flow production Method}

In this method the elements are transported on pallets through the factor from one operation to another on roller conveyors or traversers. This method is typically used for wall panels and floor units. This flow production method gives good flexibility for design.

\subsection{Long Lines of Beds}

Floor elements are particularly suitable for production on long Lines. Floor elements (precast planks) are casted on "long lines", for composite planks floors were produced on long lines. Compaction being carried out by vibratory carriages running below the bed or by external vibrators attached with quick action couplings. Large factory floor area required to this long lines. By observing this the mobile workstations and the relatively long transport distances have seen a move towards pallet production in recent days with automatic stacking and curing chambers. The computer assisted methods and mechanization bringing much advantages in this production. The CAD (design development) and CAM (production sequencing and production data acquisition) are the recent traditional area of automation.

\subsection{Types of concrete used in precast concrete construc- tion}

a) In recent years the development of concrete technology offering various types of concretes those can be used in precast concrete buildings. The types of concrete used: Normalstrength concrete, High-strength concrete, Lightweight concrete, Self-compacting concrete, and Coloured concrete etc. These concrete are preferred because the production is done in well prepared plants. The mix is prepared and placed in 
moulds in the plant. These should be poured easily and should not remain in the skip or stick to the chute.

b) Self-compacting concrete (SCC) - The flow ability of this concrete is achieved by adding very efficient plasticizer and the self-compacting effect through a suitable binder/aggregate ratio and a special grating curve. Self- compacting concrete is characterized by the fact that it flows the action of gravity until it finds an even level and in doing so releases all the entrapped air. The Advantages of SCC are no compaction necessary, less noise in the plant, extremely good fair finishes, Very good encasing of cast in parts, Heavy reinforcement possible, better mould accuracy due to the elimination of vibration [1].

c) Coloured and structured concrete surfaces- Architectural design options are available for the surface of precast elements. Apart from colour, is also possible to change the concrete mix. If the concrete surface is not treated or worked in any away after de-moulding, then it is the outermost layer of the concrete, the cement laitance that is solely responsible for the appearance of the concrete. The properties of the coarse aggregate are then irrelevant and only the constituents of the cement past- sand, cement and water need to be chosen to suit the requirements. A high water-cement ration produces a light- coloured surface. The colour depends on the type of cement (blast furnace cement $=$ light grey, white cement $=$ off white, oil shale cement $=$ brownish) and the colour of sand. By adding synthetic inorganic pigments especially iron oxide will give primarily three colours red, black and yellow are mostly used.[2].

\subsection{Heat treatment:}

The hardening phase of the precast concrete members depends on how much time is allocated to the concreting to de- moulding plan. If it is short (4hrs), then the hardening is best guaranteed by the application of heat. The simplest way is to use steam (hot water), which apart from boiler. Several steam lines at different places will be needed for long members. [1].

\subsection{Working with hard surfaces:}

The cement laitance can be washed off of the surface of the concrete as long as it is still soft. First and foremost the newly cast concrete, which exposed the aggregate. To do this the cement laitance on the surface is removed by weak acids, sandblasting of jets of water. The surfaces are cleaned and repaired/treated before sending to stalking. Only in exceptional cased necessary chemical coating is done for the components that which provide durability [1].

\subsection{Installing the reinforcement in the factory:}

Reinforcing cages for linear elements such as beams and columns are generally assembled outside of the mould, whereas the reinforcement for floor slabs is generally fixed inside the mould. Fixing the reinforcement bars directly from a coil is a technique in many plants for smaller diameters of bars. The automatic straightening and cutting machinery with which reinforcing bars are processed directly from the coil to form straight bars, there are also automatic stirrup bending machines that turn the steel into finished shear links. Fully automatic welding stations fully integrated into the production line are using nowadays, these are used to weld bars (directly from coil) already straightened and cut to length into planar reinforcement in the form of "just-in-time bespoke meshes".

\subsection{Break Even Point}

In accounting, the break-even point refers to the revenues needed to cover a company's total amount of fixed and variable expenses during a specified period of time. In other words, the breakeven point is equal to the total fixed costs divided by the difference between the unit price and variable costs [3]

\section{Theoretical framework}

Choosing a precast technology depends on the number of units to be constructed, at what point this technology is equals to the conventional building construction costs, gives understanding to Architects and construction industry. By studying a precast construction and comparing it with a conventional building with the help of Break-even point method. The material costs, labor costs, scaffolding costs and plastering cost are predominantly brings differences.

Due to high initial costs of the precast industry, Factors that affect the cost of owning and operating construction equipment include: The cost of the equipment delivered to the owner, the number of hours the equipment is used per year, the number of years the equipment is used, the care with which the owner maintains and repairs the equipment, the demand for used equipment when it is sold, which will affect the salvage value.

The benefit due to early completion means earl completion brings early returns. These factor are considered in the analysis.

\section{Case study}

\subsection{Introduction}

Location $=$ New Delhi

Area of Dwelling Unit $=40 \mathrm{~m}^{2}$

Typical Floor area of one Tower $=9022 \mathrm{~m}^{2}$

Total no of DU in one Tower $=182$ no's

Project Duration $=1095$ days

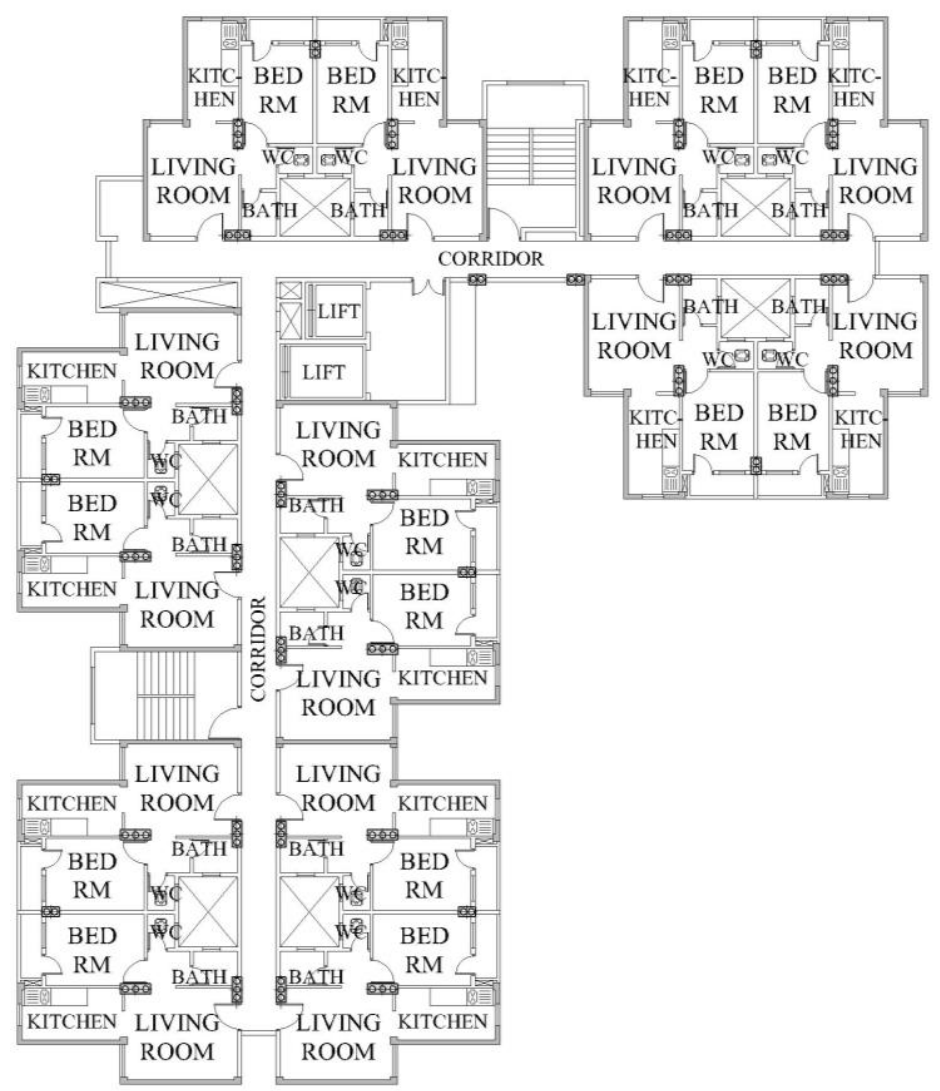

Fig. 2 Typical Floor Plan 


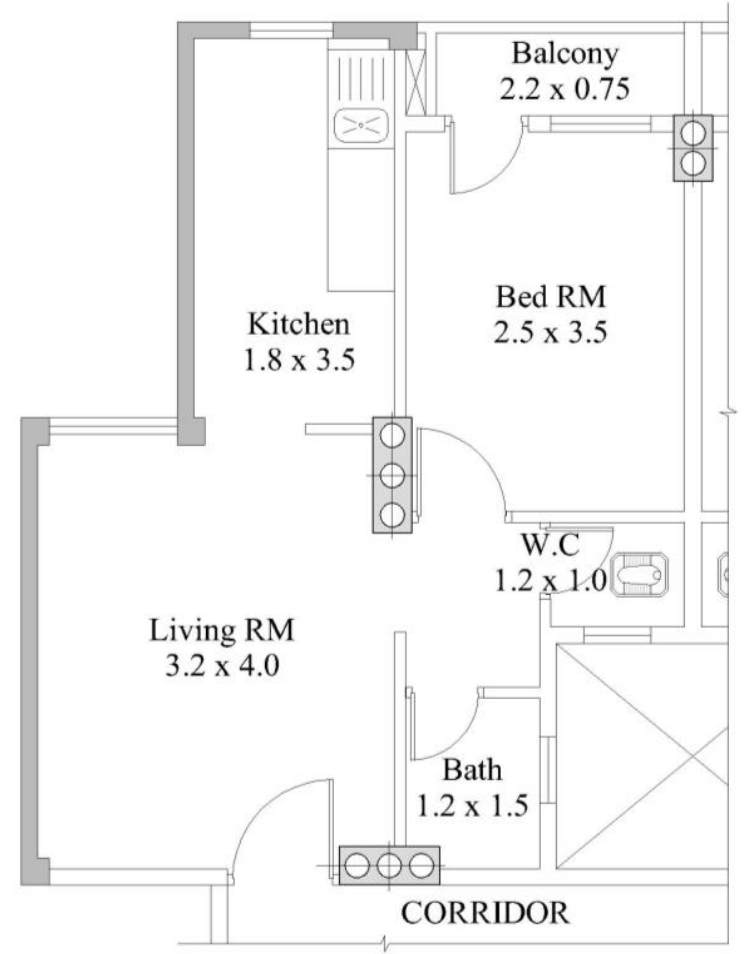

Fig. 3 Dwelling Unit (Part) Plan

\subsection{Prefabricated Technologies and Equipment used}

\subsubsection{Introduction}

Partial prefab or hybrid technology used in this project- columns, beams, stair-case and slab elements are cast in factory (casting yard) except foundation. Each element is discussed below.

\subsubsection{Foundation}

The foundation is of RCC cast in situ foundation, having typical raft depth of $850 \mathrm{~mm}$ raft over PCC bed. The depth of the foundation is $4.5 \mathrm{~m}$. The concrete is used as M 30 .

\subsubsection{Plinth beams/ Beams}

These beams are casted in factory with M-30 concrete, in special moulds. The moulds are arranged with vibrating systems to eliminate cavity in the member. Hot water cooling done for faster setting time $(6 \mathrm{hrs})$, to use the mold again. The member is checked thoroughly and minor finishing touchups dons and sent for curing then stacking. The maximum weight of the beam is $1.3 \mathrm{MT}$ $(0.35 \times 0.3 \times 5.57 \mathrm{~m})$.

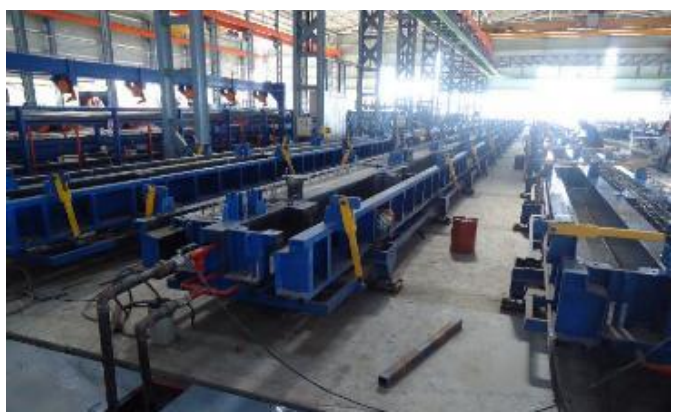

Fig. 4 Beam Casting Mould

These are specially prepared moulds with vibration arrangement and hot water supply to get finished surface, eliminate voids in the member and initial setting time to de mold for further use.

The image on the right shows the beam at factory.

\subsubsection{Columns}

The columns are casted on specially prepared moulds (Shell column), hollow in the center for jointing and light weight for transportation. The sizes are $350 \times 600 / 900 / 1150 \mathrm{~mm}$. the size of hollow potions in side having $200 \times 200 \mathrm{~mm}$. The weight of the column is $2.2 \mathrm{MT}(0.35 \times 1.15 \mathrm{~m})$.

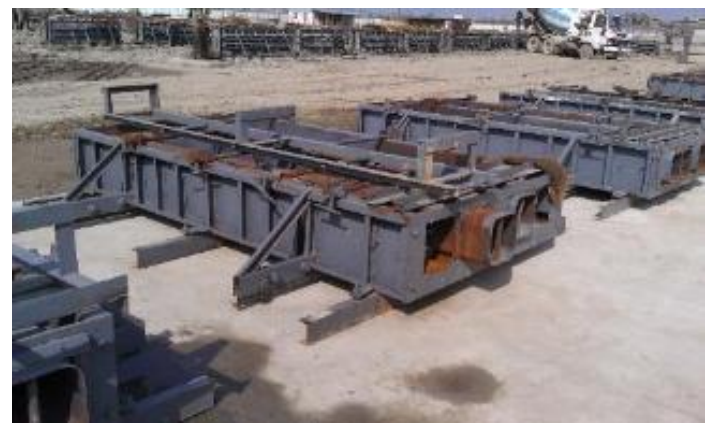

Fig. 5 Shell Column Mould

\subsubsection{Shear Walls/ Slab/Walls}

Shear walls are casted on specially prepared mechanized arrangement as vibrating tables. Concrete casted with automatic machines (comcaster) [4].

It is like a flat table with vibrating arrangement to the form of wall placed above and reinforcement is place then placed all necessary arrangement to transport and erection. Finally casted with concrete specified.

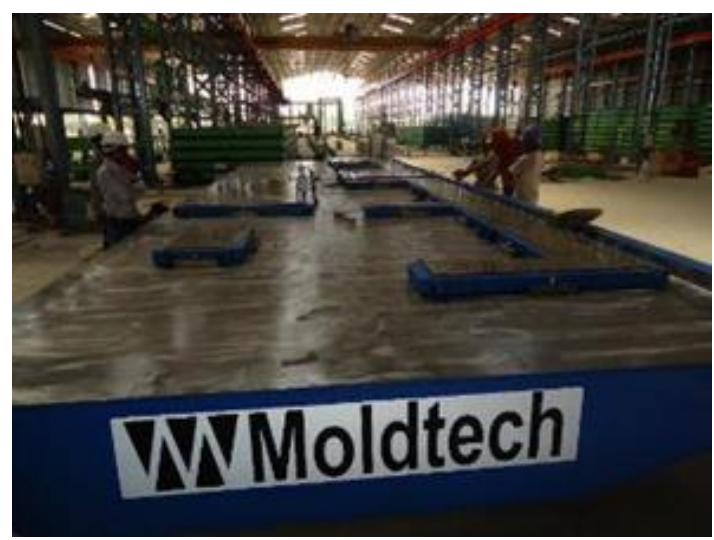

Fig. 6 Wall/ Slab casting tables

Stair case: Stair case are casted at casting yard on specially prepared moulds and cured, then stacked for erection.

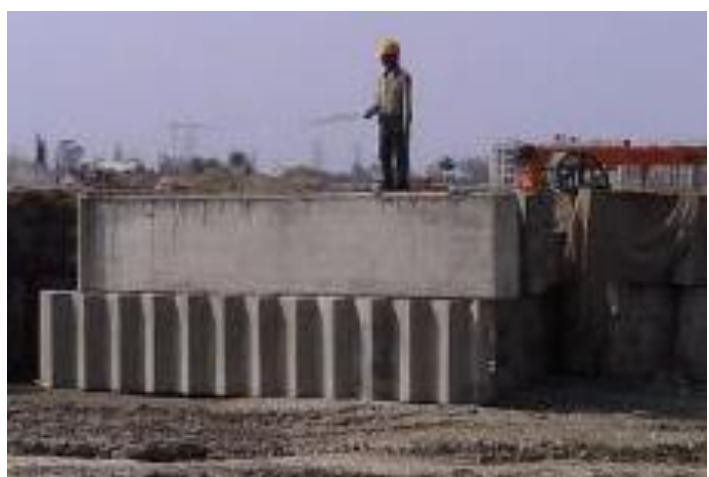

Fig. 7 Pre-cast Stair case 


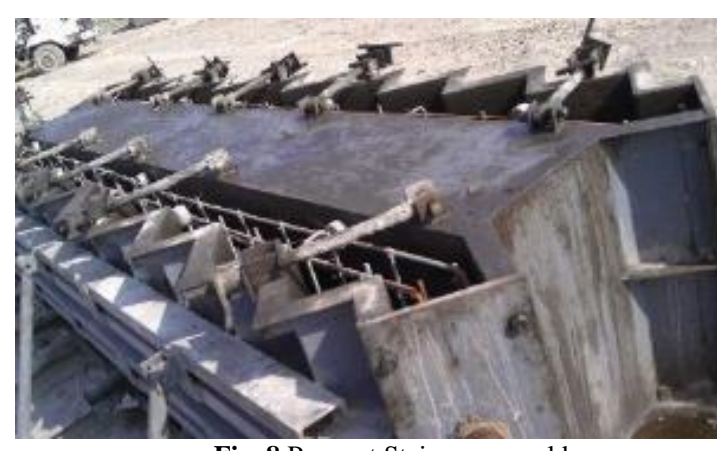

Fig. 8 Pre-cast Stair case mould

\subsubsection{Case making machine}

Automatic column and beam reinforcement/ case making machine for faster and quality of work. This is similar to the wall casting machine reinforcement mat placing with necessary arrangement to transportation and erection and casted.

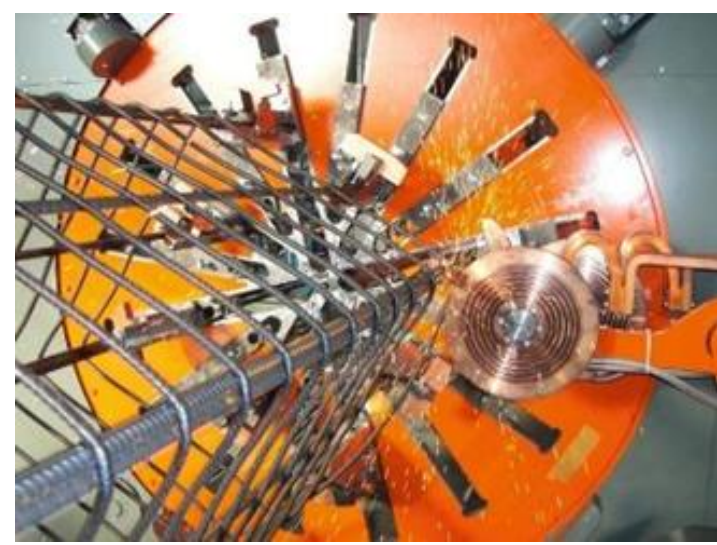

Fig. 9 Case making machine

\subsubsection{Concrete Shuttle}

Shuttle (Fast and automatic transportation of concrete to the casting machine) is to transport concrete from batching plant to the casting plant equipment to cast members.

\subsubsection{Automatic dual-direction stirrup bender}

Due to number of elements are identical this Automatic dualdirection stirrup bender machine is used to prepare strips and cut steel.

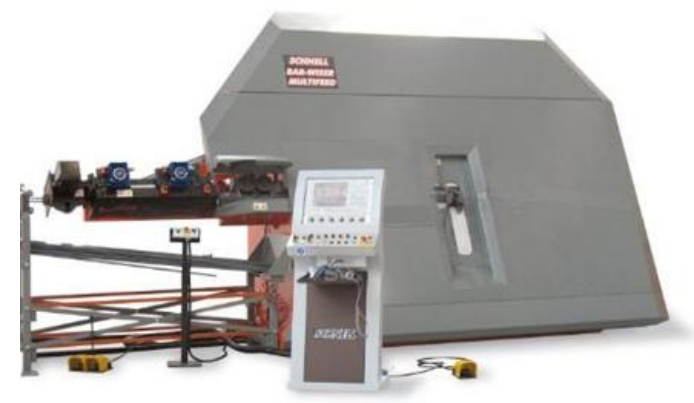

Fig. 10 Automatic dual-direction stirrup bender

\subsubsection{Transportation}

Trucks are used to transport the members to curing and stacking and to erect.

\subsubsection{Tower Crane}

Heavy duty Tower cranes are used extensively in this project to lift the P.C members in various stages (at end $5 \mathrm{t}$ capacity and radius is $35 \mathrm{~m})$.

\subsection{Erection sequence}

The building block is having $\mathrm{G}+12$ floors, the foundation is cast in situ RCC raft foundation of having $850 \mathrm{~mm}$ thick raft depth over $100 \mathrm{~mm}$ pcc bed. The typical depth of mass excavation is $4.5 \mathrm{~m}$ typical. From the raft stem/short columns and shear wall raised cast in situ up to bottom of the plinth beams bottom level by leaving dowels for shear wall and columns joint. Then precast plinth beams are placed on the stem columns/Shear walls with the help of cranes, then it is casted in situ (plinth Joint). Dowels are left for the column/shear wall. The joint shown below.

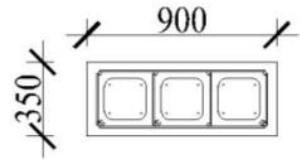

Fig. 11 Precast Shell/Hollow Column Plan

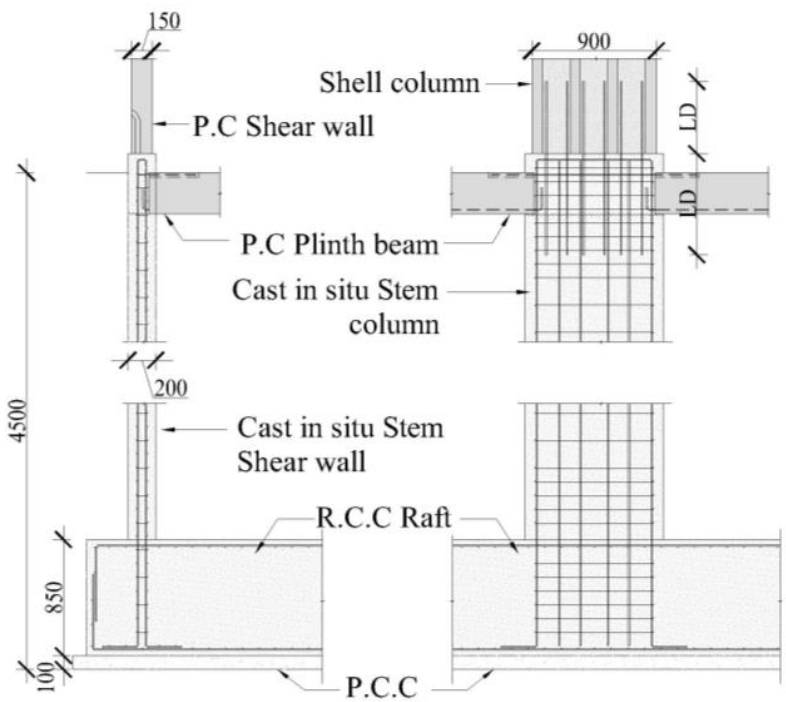

Fig. 12 R.C.C. Raft Foundation: $\mathrm{RCC}=$ reinforce cement concrete, $\mathrm{PC}=$ pre cast member

Section showing Column Joint with Stem column Precast Shell Columns are place above the joint with the help of heavy duty cranes the number 4 in shows in the above detail.

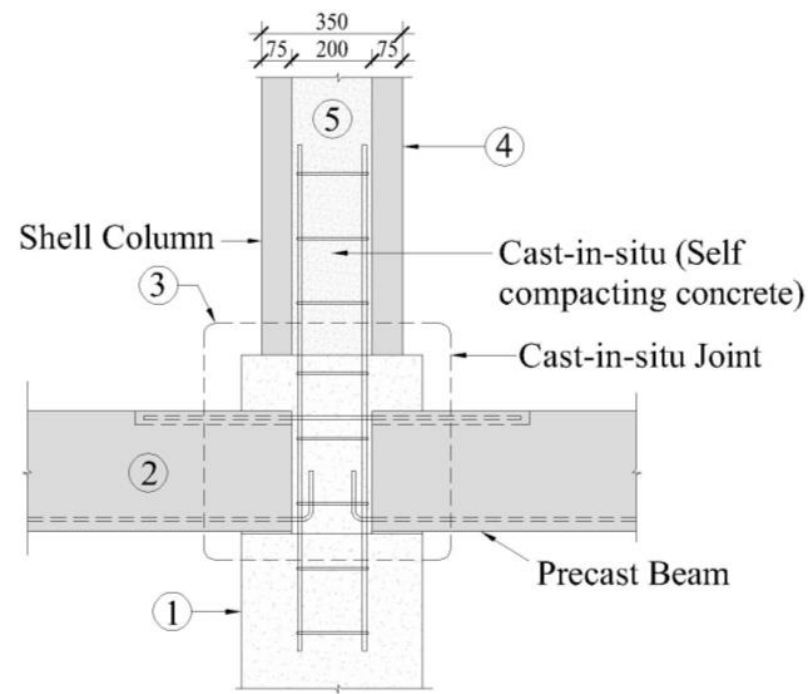

Fig. 13 Column and Plinth beam joint.

Column and Plinth beam joint erection from figure 13:

1. Cast in situ Foundation Stem Column/Shear wall 2. Beams placed over the pedestal and tied with reinforcement 3. Casting of joint in situ 4. Placing of column on the pedestal of joint 5. Cast in situ self-compacting concreting. 
This column are place with props/steel strings to stand in position, then the hollow portion of the column is concreted with selfcompacting concrete of M30 (in situ) poured from above. These columns and shear wall are casted in such a way to house the beams and slabs at top. The weight of the column is 2.2 MT $(0.35 \times 1.15 \mathrm{~m})$.

The Pre cast beam are placed over the columns then Pre cast slab panels are placed. The minor gaps are filled on site with rich motor by manually. The $40 \mathrm{~mm}$ cast in situ screed concreting is done over the slabs and beam by place electrical conduits and plumbing sleeves. In this away each floor is done the structure. All precast members are casted in Casting yard (Factory), and well cured before shifting to site, then transported to erection by trucks and placed with cranes.

Below images shows the sequence of placing precast beam and slab and screed concrete. Fig. 13-19 Erection sequence.

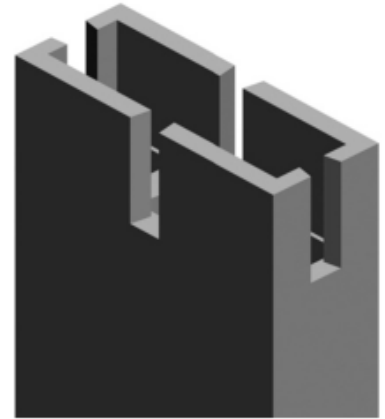

Fig. 13

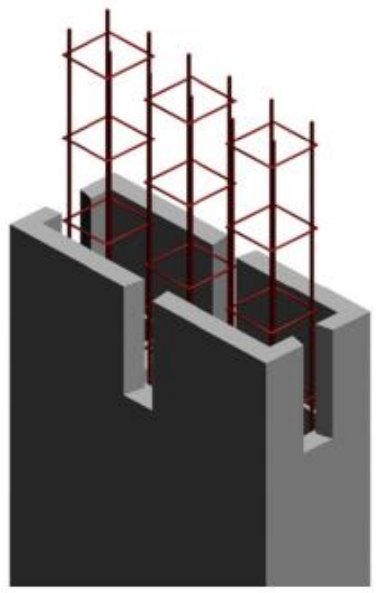

Fig. 14

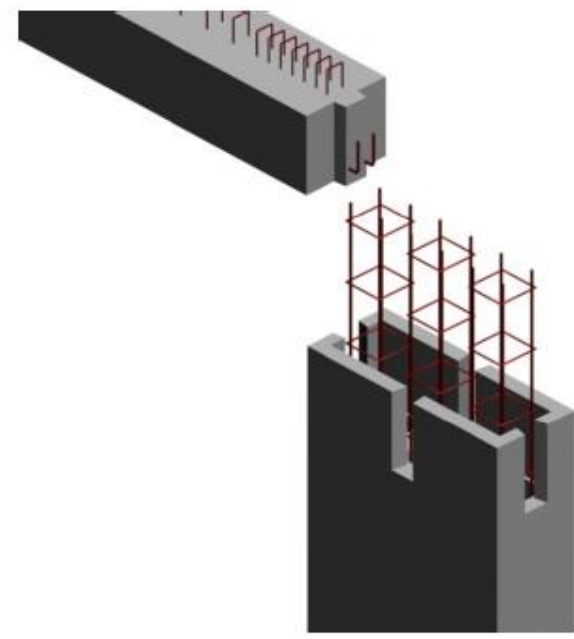

Fig. 15

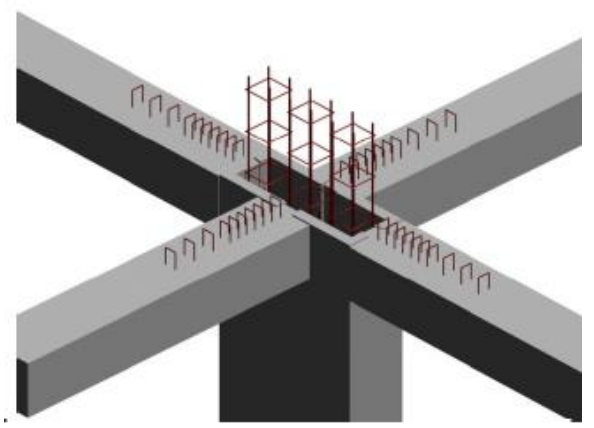

Fig. 16

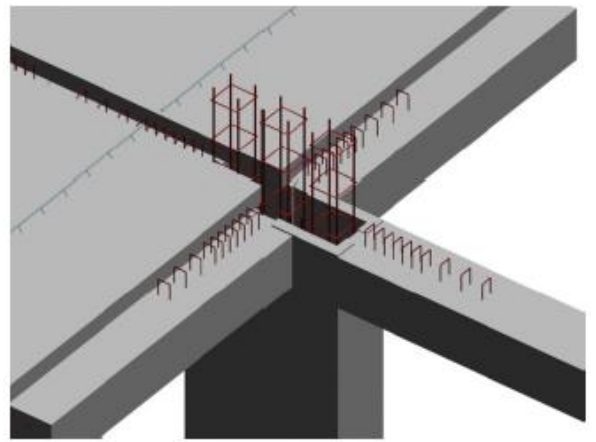

Fig. 17

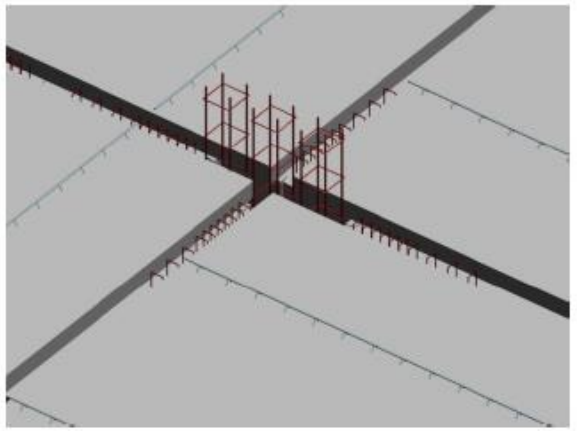

Fig. 18

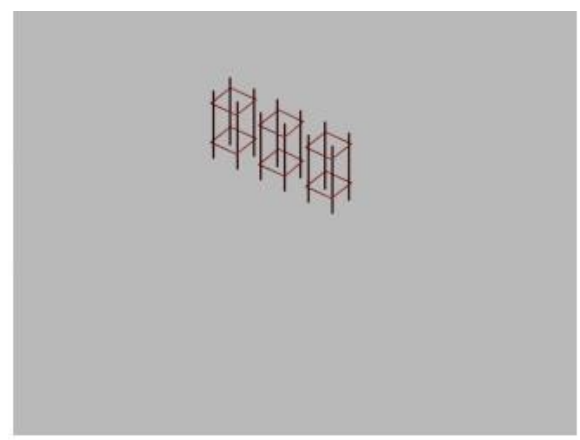

Fig. 19 


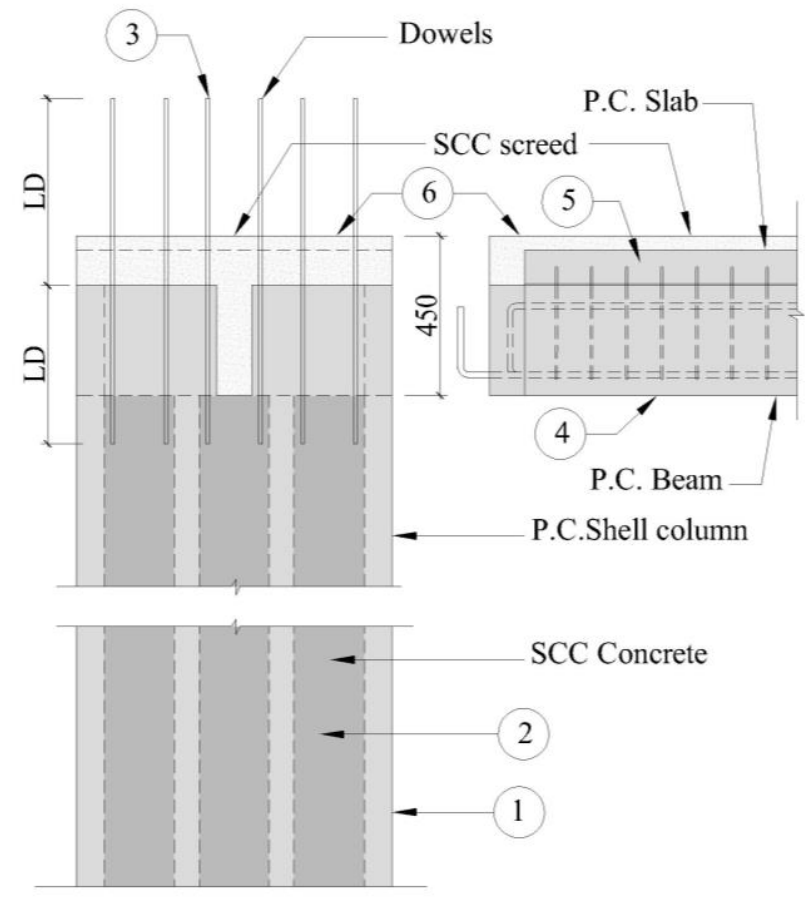

Fig. 20 Erection of beam and slab: P.C = Pre Cast, $\mathrm{SCC}=$ Self Compacting concrete

Column and Beam erection sequence from figure 20:

1. Placing the Shell column 2. Poring the SCC concrete in the shell column 3. Placing the reinforcement at the floor joint while poring the SCC in the column 4. Placing the beam in the position 5. Placing the slab panels over the beams 6 . Cast in situ concrete over the P.C. slab by placing reinforcement over slab.

Likewise the cycle repetition takes place.

\section{Details of conventional building}

Project: residential building $(\mathrm{G}+12)$

Typical Floor Plate area: $626 \mathrm{~m}^{2}$

Total Built-up area: $8138 \mathrm{~m}^{2}$

Foundation: Cast in situ Raft foundation

Structural system: RCC cast in situ framed structure

Duration of construction of total construction $=1460$ days

Per $\mathrm{m}^{2}$ cost Structure $=15,595.81 \mathrm{Rs}$.

(Including: Foundation, Columns, Beams, Slabs and Plastering; Martials, Equipment and labor cost)

\section{Findings}

This Section describes the factors affecting the time and cost in the precast construction.

1. Hot water curing is reducing the initial setting time, so that the moulds can be used number of times in a day.

2 . The vibrating arrangement for beam, walls and slabs providing a finished surface, so that plastering is not needed.

3. Shuttering is not required due to precast shell columns

4. Shuttering is not required due to precast slabs

5. Due to use of various machinery like automatic stirrup making machine, cage making machine, tower cranes the number of labor required are very less

6. Early completion yields early returns

\section{Comparisons}

Graph 1: Project Schedule up to structure
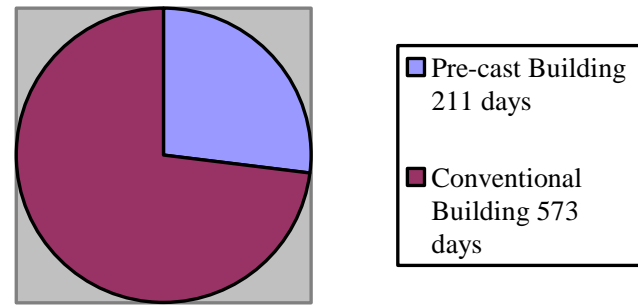

Graph 2: Labor Cost Component per $\mathrm{m}^{2}$ Built-up area

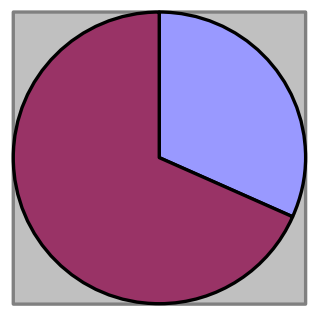

$\square$ Pre-cast Building 787.35 Rs

$\square$ Conventional Building 1702.94 Rs

Graph 3: Shuttering Quantity per $\mathrm{m}^{2}$ built-up area

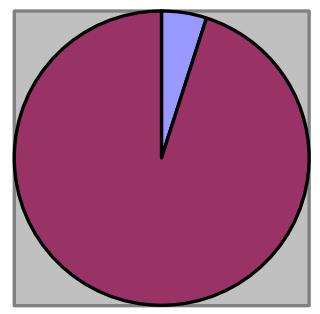

$\square$ Pre-cast Building $0.12 \mathrm{~m}^{2}$

$\square$ Conventional

Building $2.24 \mathrm{~m}^{2}$

Graph 4: Plastering Material per $\mathrm{m}^{2}$ built up area

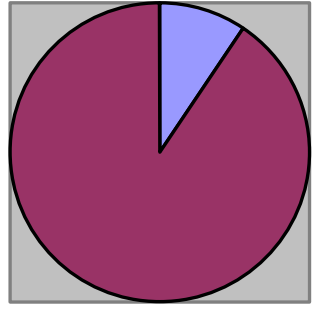

$\square$ Pre cast Building $0.47 \mathrm{~m}^{2}$

$\square$ Conventional

Buidinng $4.45 \mathrm{~m}^{2}$

Graph 5: Initial cost per $\mathrm{m}^{2}$ built up area

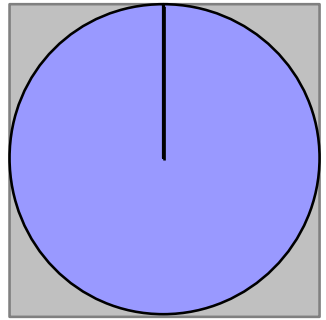

$\square$ Pre cast Building 2100000000 Rs

$\square$ Conventional

Building

15595.81 Rs

\section{Analysis}

The initial costs are very high for precast construction but the mass production and repetition brings down the cost. 
Table 1: Finding out Break-even Point

\begin{tabular}{|c|c|c|}
\hline \multicolumn{3}{|c|}{ Calculations } \\
\hline & Initial investment in Rs. & $21000,00,000.00$ \\
\hline & $\begin{array}{l}\text { Annual Maintenance } \\
\text { (10\% of investments) }\end{array}$ & $2100,00,000.00$ \\
\hline A & $\begin{array}{l}\text { Total cost component } \\
\text { from factory }\end{array}$ & $23100,00,000.00$ \\
\hline $\mathbf{B}$ & $\begin{array}{l}\text { Cost Component } \\
\text { Per/m² Built up area } \\
\text { (Including all) }\end{array}$ & 7007.00 \\
\hline & $\begin{array}{l}\text { (Including Foundation, } \\
\text { RCC Frame Structure } \\
\text { and Plastering work) }\end{array}$ & \\
\hline $\mathbf{C}$ & $\begin{array}{l}\text { Cost of conventional build- } \\
\text { ing } / \mathbf{m}^{2} \text { built up area } \\
\text { (Including Foundation, RCC Frame } \\
\text { Structure and Plastering work) }\end{array}$ & 15595.81 \\
\hline $\bar{D}$ & $\begin{array}{l}\text { Area required to build } \\
\text { in } \mathrm{m}^{2}\{\mathrm{~A} /(\mathrm{C}-\mathrm{B})\}\end{array}$ & 268954.51 \\
\hline & $\begin{array}{l}\text { Number of Building } \\
\text { Blocks Need to Build } \\
\text { (D/9022) }\end{array}$ & 29.81 \\
\hline & Say 30 Building Blocks & \\
\hline
\end{tabular}

Table 2: Finding out Break-even Point

\begin{tabular}{|c|c|c|}
\hline \multicolumn{3}{|c|}{ Calculations } \\
\hline & $\begin{array}{l}\text { Initial investment - Factory } \\
\text { cost Rs. }\end{array}$ & $21000,00,000.00$ \\
\hline & Factory Life (in Years) & 10.00 \\
\hline & $\begin{array}{l}\text { Annual Maintenance (10\% } \\
\text { of investments) }\end{array}$ & $2100,00,000.00$ \\
\hline & $\begin{array}{l}\text { Resale value after one year } \\
\text { (60\% of initial investment) }\end{array}$ & $12600,00,000.00$ \\
\hline $\mathbf{A}$ & $\begin{array}{l}\text { Total cost component } \\
\text { from factory }\end{array}$ & $8400,00,000.00$ \\
\hline $\mathbf{B}$ & $\begin{array}{l}\text { Cost Component Per/m² } \\
\text { Built up area (Including } \\
\text { all activities- Structure, } \\
\text { Internal block work and } \\
\text { Plastering) }\end{array}$ & 7007.00 \\
\hline $\bar{C}$ & $\begin{array}{l}\text { Cost of conventional building } \\
/ \mathbf{m}^{2} \text { built up area } \\
\text { (Including Foundation, RCC Frame } \\
\text { Structure, Internal Block work and } \\
\text { Plastering work) }\end{array}$ & $15,595.81$ \\
\hline $\mathbf{D}$ & $\begin{array}{l}\text { Area required to build in } \\
\mathbf{m}^{2}=\{\mathrm{A} /(\mathrm{C}-\mathrm{B})\}\end{array}$ & 97801.64 \\
\hline & $\begin{array}{l}\text { Number of Building Blocks } \\
\text { Need to Build (D/9022) }\end{array}$ & 10.84 \\
\hline & Say 11 Building Blocks & \\
\hline
\end{tabular}

\section{Conclusion}

The conclusions drawn from studying the case study and literature, and Comparison.

1. The precast RCC buildings leads to reduction in cost when the considerable volume (repetitions) is adopted, in comparison with Cast-in situ construction.

2. The initial costs are high in comparison with Cast-in situ construction.

3. The analysis shows man power (labor) is less in case of precast RCC buildings, in places where construction workers are so costly this method is very stable.

4. Shuttering quantity is very less

5. Material saving in plastering to the concrete surfaces also will add advantage

6. It is observed in the case study noise levels and pollution are very less, in case of extension of existing hospitals and school building it suits well.

7. Where the repletion of the building will takes place like residential, hospitals, schools and Hotels rooms this technology is very suitable.
8. Projects like time is the essence of the contract precast technology can be adopted.

9. Early completion Leeds early occupation, that gives the healthy living conditions to the occupants in case of urban poor.

10. In terms of security (in consideration of private projects) people get their own flat on investment at early time than conventional building.

11. The construction shall take place during night times also.

12. Because of the main construction takes place at the casting yard or in factory there is minimum dust and noise pollution at the site.

13. The casting occurs in controlled environment waste of material is insignificant.

\section{Acknowledgement}

I take this opportunity to thank Prof. Dr. Virendra Kumar Paul former H.O.D. Dept. MBEM, SPA, New Delhi; Prof Y.K Jain, former H.O.D. Dept. MBEM, SPA, New Delhi; and Mr. Salman Khursheed, Faculty, Dept. MBEM, SPA, New Delhi.

My sincere thanks to officials from DDA and BG Shrike Group of Companies, all who supported.

\section{References}

[1] Hubert Bachmann/ Alfred Steinle, 'Precast Concrete Structure'.

[2] M.Levitt, 'Precast Concrete Materials, manufactures and usage'.

[3] https://www.investopedia.com/terms/b/breakevenanalysis.asp last visit 15.11.2017

[4] www.elematic.com last visit:15.11.2017. 